\title{
Covid-19 Pandemisinin Girişimcilik Yazınına Yansıması
}

\author{
Reflection of Covid-19 Pandemic on Entrepreneurship Literature
}

\author{
Oytun Boran SEZGIN ${ }^{a}$ \\ ${ }^{a}$ Dr. Öğretim Üyesi, Dokuz Eylül \\ Üniversitesi, İzmir, Türkiye, \\ boran.sezgin@deu.edu.tr, \\ ORCID: 0000-0002-6671-8053
}

\begin{abstract}
ÖZ
Covid-19 pandemisi sadece sağlık alanında değil ekonomik ve sosyal anlamda da bir krize dönüşmektedir. Yaşanan gelişmelerin girişimcilik faaliyetleri açısından hem firsat hem de tehdit oluşturması, Covid-19 pandemi sürecinde girişimcilik ile ilgili araştırmaların artışına neden olmaktadır. Araştırmanın amacı Covid-19 pandemisi ile girişimcilik olgusunu birlikte değerlendiren yazının konuyu nasıl irdelediğini anlayabilmek ve bu çalışmaları yöntem ve içerik açısından sorgulamaktır. Sistematik yazın taraması olarak gerçekleştirilen çalışmada, taramalar sonucunda 72 bilimsel çalışma tespit edilerek, 10 farklı ölçüt çerçevesinde sınıflandırılmıştır. Yapılan analizler doğrultusunda, ilgili çalışmaların orijinal makaleye yakın seviyede perspektif/görüş/yorum türünü benimsediği, mikro ile mezo düzeyde çalışmaların makro çalışmalara oranla daha fazla tercih edildiği, araştırma hedefinin betimleyici çalışmalarda yoğunlaştığ tespit edilmiştir. Girişimcilik alanındaki araştırma nişleri açısından çalışmaların; girişimsel firsat, işletme kurulumu ve sosyal girişimcilik temalarını tercih ettikleri bulgulanmıştır. Elde edilen sonuçlar, Covid-19 pandemisi düzleminde girişimcilik araştırmalarının hangi niş alanlara odaklanıldığını ortaya koyarak konuyla ilgili araştırmacılara yol gösterici olacağı umulmaktadır.
\end{abstract}

Anahtar Kelimeler: Girişimcilik, Covid-19, Girişimsel Fırsat, Sosyal Girişimcilik.

\begin{abstract}
The Covid-19 pandemic turns into a crisis not only in the health field but also in the economic and social. The developments that are experienced create both opportunities and threats in terms of entrepreneurship activities, causing an increase in research on entrepreneurship during the Covid-19 pandemic. The purpose of the research is to understand how the studies, which evaluate the Covid19 pandemic and entrepreneurship phenomenon together, examines the issue. In the study, which was carried out as a systematic literature review, 72 scientific studies were determined as a result of the preliminary assesment and classified under 10 different criteria. In line with the analyzes conducted, it was determined that the relevant studies adopted the perspective / opinion / commentary studies at a level as many as original article, micro and meso level studies were preferred more than macro studies, and the research objective was concentrated on descriptive studies. In terms of research niches in the field of entrepreneurship; It was found that relevant studies preferred entrepreneurial opportunity, business establishment and social entrepreneurship themes. It is hoped that the results obtained will guide researchers on the subject by revealing which niche areas entrepreneurship research focuses on in the plane of the Covid-19 pandemic.
\end{abstract}

Keywords: Entrepreneurship, Covid-19, Entrepreneurial Opportunity, Social Entrepreneurship

\footnotetext{
* Bu makalede bilimsel araştırma ve yayın etiği ilkelerine uyulmuştur. / In this article, the principles of scientific research and publication ethics were followed.
} 


\section{GíRiş}

2019'un son döneminde Çin'de başlayıp 2020 yılının Mart ayında küresel bir salgın olarak kabul edilen Covid-19 olarak adlandırılan korona virüsü (WHO, 2020) dünyayı hazırlıksız yakalamıştır (Bacq, Geoghegan, Josefy, Stevenson ve Willams, 2020). Sınırların kalktığı bir dünyada örgütlerin hayatta kalmalarını tehdit edebilecek Covid-19 gibi önemli problemler, örgütlerin tepki verebilen ve uyum sağlayabilen bir yapıda olmalarını gerektirmektedir (Carnavale ve Hatak, 2020). Tecrit, sosyal mesafe gibi yeni düzenin yeni olguları, üretim ve tüketim süreçlerini değiştirirken iş hayatını da bu yeni duruma/normallere uyum sağlamaya zorlamıştır (Batat, 2020). Söz konusu değişimler, küçük ölçekli işletmelerin gelir elde edememesinden dolayı finansal krize girme riskinden (Cowling, Brown ve Rocha, 2020) yeni girişimler için sermaye bulamamaya (Rocha ve Brown, 2020), sosyal gereksinimlerin karşılanması için sosyal girişimcilik faaliyetlerinden (Ratten, 2020c) girişimcilerin yaşadığı sorunlara (Omar, Ishak ve Jusok, 2020) kadar neredeyse tüm girişimcilik faaliyetlerini etkilemektedir. Dahası, McKinsey Küresel Enstitüsü'nün raporu (McKinsey Global Institute, MGI) ekonomik daralma süresinin ekonomik kırılganlığa bağlı olarak değişkenlik göstereceğini tartışırken; söz konusu krizin 5 yılı aşabileceği, hatta küçük ölçekli işletmeler için daha da uzun sürebileceği ve bu süreçte işletmelerin kapanabileceği bir kriz yaşanabileceğini ortaya koymaktadır (www.mckinsey.com). Görünen o ki, pandemi sürecindeki yaşanan dönüşüm uzun dönemli bir çevresel belirsizlik yaratarak mikro düzeyde girişimcilik faaliyetlerinden makro düzeydeki girişimcilik ekosistemine 'yeni normal' bir düzen yaratacaktır.

Özellikle ekonomik büyüme (Baumol, 1968: 65), inovasyon (Wennekers ve Thurik, 1999: 51), istihdam (Acs ve Armington, 2004: 922), ekonomik yenilenme (Tödtling ve Wanzerböck, 2003: 351) gibi ülke ekonomisi açısından önem arz eden birçok konuyu olumlu yönde etkileyen girişimcilik olgusu bağlamında yaşanan dönüşümler hem tehditler hem de firsatlar yaratmaktadır. Düşük dirençli ekonomiler için Covid-19 gibi dış şokların üstesinden gelme konusunda girişimciliğin gelişmesi çok önemlidir (Cannavale, Nadali ve Esempio, 2020). Çünkü girişimcilik inovatif düşünce yapısı ile refah yaratarak diş şoklarla gelen ekonomik çöküşün iyileşmesi için umut kaynağı olmaktadır (Czarniawska-Joerges ve Wolff, 1991: 542). Kısacası Covid19 pandemisi girişimcilik faaliyetlerine yönelik tehditleri barındırırken aynı zamanda değişen şartların şekillendirdiği yeni talebin yarattığ fırsatların inovasyon ile çözülebileceği gerçeği, yaşanan ekonomik daralmanın da girişimcilik faaliyetleri ile aşılabileceğini göstermektedir. Dolayısı ile Covid-19 pandemisinin girişimcilik olgusu ile etkileşimi birçok araştırmacının konuya yönelik ilgisini doğurmaktadır.

Alana yönelik oluşan ilgi doğrultusunda girişimcilik ve Covid-19 pandemisi ile ilgili araştırmaların nasıl seyrettiği ise bir başka merak konusudur. Özellikle pandemi krizinin yaralarını sarma açısından önemli bir etkisi olacağı düşünülen girişimcilik olgusunun, Covid-19 pandemisi sürecinde nasıl tartışıldığının anlaşılması sonraki araştırmalara yön göstermesi açısından önemlidir. Yazında Covid-19 pandemisi ile girişimcilik olgusunu birlikte irdeleyen çalışmaları sınıflandıran ya da değerlendiren bir çalışmaya rastlanmamıştır. Bu araştırmanın amacı, Covid-19 pandemisi düzleminde girişimcilik olgusunu tartışan çalışmaları içerik ve yöntemsel olarak sınıflandırmaktadır. Dünyada küresel bir salgın olarak Covid-19'un kabul edildiği Mart ayından Kasım ayına kadar Covid-19 pandemisi ile girişimciliği birlikte değerlendiren bilimsel çalışmaların nasıl şekillendiği, hangi bilimsel çalışma türünün tercih edildiği, girişimcilik alanında hangi düzeyde çalışmaların gerçekleştirildiği, söz konusu araştırmaların hangi araştırma hedefi ile tasarlandığı, konu ile ilgili yazılmış olan orijinal makalelerin hangi araştırma yöntemi ile veri toplama tekniğinden faydalandığı ve çalışılan araştırma nişlerinin hangileri olduğu çalışmanın ilgi odağıdır. Bu doğrultuda, çalışmanın ilk bölümünde girişimcilik olgusu tartışılacak, sonraki bölümde araştırmanın yöntemi aktarılacaktır. Bulguların belirtilmesinden sonra sonuç ve tartışma bölümünde elde edilen bulgular değerlendirilecektir.

\section{YAZIN TARAMASI}

Akademik ve iş hayatında uzun süredir tartışılan girişimcilik kavramı, insanlar arasındaki ticaretten beri uygulamada mevcutken kavramın ilk tanımlaması 18. Yüzyılda bankacı olan Richard Cantillon tarafindan yapılmıştır (Dorin ve Alexanduru, 2014: 445). Cantillon'a göre (1755) girişimci ham maddeyi belli olmayan bir fiyattan satmak için belli bir fiyattan satın alan kişidir (Aktaran: Fillion, 2011: 43). Cantillon'dan sonra önemli katkıyı yapan Say’e göre (1815) girişimci, değer katan faaliyetleri yaratan bir ekonomik aktördür (Aktaran: Fillion, 2011: 43). O dönemde tanımlar yapılmasına karşın klasik iktisat teorileri, girişimciliği teorilere yerleştirme konusunda zorluklar yaşadıkları için girişimciyi ve girişimciliği göz ardı etme eğiliminde olmuşlardır (Swedberg, 2002: 11). Bu noktada inovasyon ve girişimciliği iktisat teorisine yerleştirerek ekonomik büyümedeki önemini ortaya koyan Schumpeter, inovasyonun 'devrimsel' değişimini ekonomik gelişmenin temelinde görmüş ve dinamik yapının temel taşı olan girişimciliği ön plana çıkartmıştır (Sledzik, 2013: 89).

Her ne kadar 1980’lere kadar Shumpeteryan ekonomi ve girişimcilik unutulmuş olsa da (Sledzik, 2013: 89) özellikle rekabet üstünlüğü açısından inovasyonun öneminin anlaşılmasıyla (Lengnick-Hall, 1992) girişimcinin rolü tekrar hatırlanmıştır (Czarniawska-Joerges ve Wolff, 1991: 536). Fakat önceki dönemde görece birey düzeyinde incelenen girişimcilik olgusu örgüt düzeyinde de incelenen bir alanı şekillendirmiştir. Ek olarak örgüt içinde birey düzeyinde girişimcilik faaliyetleri ile ilgili olarak iç girişimci olgusu da daha detaylı olarak incelenmeye başlanmıştır. Çünkü iç girişimcilerin yüksek eğitim seviyesi ile edindikleri bilgiyi inovasyona ve inovasyonda başarıya götürmek için kullanabilmeleri ve bir anlamda örgütün girişimsel kapasitesini geliştirebilmeleri (Cadar ve Badulescu, 2015: 658) ile işletmelerin rekabet üstünlüğü elde etmelerinde önemli bir unsur (Burgelman, 1983: 230) olarak görülmeye başlanmıştır.

Örgütlerin çevrelerine uyum sağlayabilmek adına uyguladıkları stratejilerden (Miles, Snow, Meyer ve Coleman, 1978: 549559) çevresel firsatları takip eden örgütlerin daha başarılı olması (Snow ve Hrebiniak, 1980: 334; McKee, Varadarajan ve Pride, 1989: 30) işletmeleri yenilikçi olmaya zorlamaktadır (Kuratko ve Hodgetts, 1988: 55). Örgütlerin girişimciliklerini inceleyen alan dahilinde ilk ana akım; örgütsel kapsamda girişimciliği neyin oluşturduğunu sorgularken, örgütlerdeki hangi davranışın 
sergilendiği ya da performans veya beklenen performansın ne olduğu ile ilgilenmemektedir (Audretsch, 2012: 756). Firma düzeyinde de öncelikli olarak yeni girişim sürecine yoğunlaşılırken ilerleyen dönemde firma düzeyindeki girişimciliğin sürecine ve uygulamalarına yönelik ilginin artığı gözlenmektedir (Low ve MacMillan, 1988; 146-151; Covin ve Slevin, 1991: 7). Firma düzeyinde girişimcilik faaliyetleri, örgütlerin girişimsel çıktılarına odaklanan kapsam yönelimli ve örgütlerin girişimsel özelliklerini örgüt içi davranış ve iklim üzerinden inceleyen süreç yönelimli olmak üzere iki odak (Antoncic ve Hisrich, 2003) ile şekillenmektedir.

Bir girişimin çevresini oluşturan sektörün, rekabetçi ya da işbirlikçi koşulları ile girişime nasıl bir etki ettiği girişim açısından fark yaratmaktadır (Van de Ven, Hudson ve Schoeder, 1984:87). Dolayısıyla, girişimcilik alanındaki çalışmaların birey ve örgüt düzeyi dışında tüm sektörü ya da tüm toplumu kapsayacak biçimde çeşitli analiz düzeylerinde araştırmaların yapıldığı gözlenmektedir (Low ve MacMillan, 1988: 151-152). Girişimcilik ekosistemi ya da girişimsel ekosistem olarak da adlandırılan söz konusu çerçeve; hükümetler, üniversiteler, yatırımcılar, danışmanlar, hizmet sağlayıcılar, medya ve büyük ölçekli işletmeler gibi birçok bağımsız aktörden oluşurken, girişimsel faaliyetlerin seviyesini ve gelişimini doğrudan etkilemektedir (Hechavarria ve Ingram, 2019: 431).

Wortman'a göre (1897: 262) birey düzeyindeki çalışmalar işlevsel olarak yeni girişim, girişimci uygulamaları, girişimcilerin gerçekleştirdiği iş birlikleri ya da diş paydaşlarla etkileşimi mikro yapısal alanı oluşturmaktadır. Diğer taraftan girişimci bireylerin kişilik, demografik, iş özellikleri ya da kariyer algıları gibi merak konuları ise mikro davranışsal alanı şekillendirmektedir. Örgüt düzeyindeki araştırmalar da birey düzeyi gibi işlevsel olarak iki başlık altında toplanmaktadır. Yeni girişim kurulumu, yeni iş modelleri, yatırım, inovasyon ya da teknoloji yönetimleri üzerinden örgütlerin girişimciliğini tartışan alan yapısal alandır. Örgüt düzeyindeki diğer alan, örgütlerin yönetsel uygulamaları ve iklimleri üzerinden girişimci özelliklerine yoğunlaşan örgüt düzeyindeki davranışsal alandır. Wortman’a göre (1987: 262) girişimcilik faaliyetlerini çevreleyen alan ise makro çevreyi oluşturmaktadır.

\section{YÖNTEM}

Sistematik literatür taraması olarak gerçekleştirilen araştırmanın amacı Covid-19 pandemisinin girişimcilik alanına yansımasını irdelemektir. Bu bağlamda çalışmaların; iki alanı bütünsel incelemeleri, kaç yazarlı bir çalışma gerçekleştirildiği, yayınlandıkları endekslerin ne olduğu, anahtar kelime tercihleri, bilimsel çalışmanın türü, araştırma hedefleri, girişimcilik olgusunun düzeyi, orijinal araştırmaların yöntemi ve ilgili girişimcilik araştırma nişleri sorgulanmıştır. Nitel yaklaşımla tasarlanan çalışmada, araştırmanın popülasyonunu Covid-19 pandemisi ve girişimcilik olgularını birlikte değerlendiren Web of Science'ta kayıtlı bilimsel çalışmalar oluşturmaktadır. İlgili bilimsel çalışmaları tespit edebilmek için 'Web of Science Core Collection' veri tabanının arama alanında ilgili alanları temsil edebilecek anahtar kelimeler kullanılmıştır. 'Web of Science Core Collection' veri tabanının tercih edilmesinin nedeni, yüksek güvenilirlik ve veri tabanına dahil olacak dergi seçimindeki kaliteyi ve etkiyi değerlendiren 28 ölçütten faydalanmasıdır. Girişimcilik alanının mikro, mezo ve makro düzeylerini kapsaması için çeşitli anahtar kelimeler tercih edilmiştir. Bu doğrultuda 'Girişimcilik' (Entrepreneurship), 'Girişimci' (Entrepreneur), 'İç Girişimci' (Intrapreneur), 'Girişimsel' (Entrepreneurial) ve 'İç Girişimcilik' (Intrapreneurship) anahtar kelimeleri seçilmiştir. Birey düzeyinde bağımsız ve kurumsal girişimciler olarak ayrılan iki alanı kapsamak adına girişimci ve iç girişimci, mezo düzeyde kurumsal girişimcilik ve girişimsel yönelimi kapsayan girişimcilik ve girişimsel, makro düzeyde de girişimcilik ekosistemini kapsayan çalışmalara ulaşabilmek için girişimcilik anahtar kelimeleri seçilmiştir. Alandaki tüm faaliyetleri tanımlayan girişimcilik ve iç girişimcilik kelimeleri de anahtar kelimeler içerisinde yer almaktadır. Covid-19 pandemisi içinse 'Covid' (Covid), 'Korona Virüs' (Coronavirus) ve 'Pandemi' (Pandemic) anahtar kelimeleri tercih edilmiştir. Her alandan birer anahtar kelime ile toplam 12 ayrı tarama gerçekleştirilmiştir. Tarama sürecinde her iki alanın ortak paydası olan bilimsel çalışmalar araştırmanın ilgi odağını oluşturduğu için anahtar kelimeler 'AND' ile kullanılmış ve olabildiğince ilgili tüm bilimsel çalışmalara erişebilmek adına 'konu' (Topic) üzerinden tarama yapılmıştır.

Gerçekleştirilen 12 tarama sonucunda toplam 231 bilimsel çalışmaya erişilmiştir. 'İç Girişimcilik’ ve 'İç Girişimci’ anahtar kelimeleri ile eşleşen bir çalışmaya rastlanmamıştır. Erişilen bilimsel çalışmaların önemli bir kısmı (141 tane) iki olgunun taramasında değerlendirilen farklı anahtar kelimelerin birden fazlasını bilimsel çalışmada kullandığı için farklı taramalarda mükerrer olarak tespit edilmiştir. Diğer taraftan, pandemi anahtar kelimesi sadece Covid-19 pandemisini vurgulamadığı için tarama sırasında araştırmanın ilgi odağı dışında kalan çalışmalar da tespit edilmiştir. Bu nedenle, girişimcilik ile ilgili üç, girişimei ile ilgili dört ve girişimsel anahtar kelimesi ile ilgili iki bilimsel çalışma olmak üzere toplam sekiz çalışma ilgisiz oldukları nedeniyle örneklem dışında bırakılmıştır. Öte yandan bir çalışma (van den Hoogen vd., 2020) konuyu viroloji bağlamında tartışması, her ne kadar girişimsel yöntemle inovatif yaklaşımların virüs tedavisinde faydalı olacağını belirtse de alan dışı olması nedeniyle örneklem dışında bırakılmıştır. Öte yandan taramalar sırasında üç bilimsel çalışmanın tam metnine erişilememiştir. Ek olarak beş bilimsel çalışmanın ise yazım dili İngilizce olmaması nedeniyle (iki Rusça, iki İspanyolca, bir Fransızca) örneklem dışında bırakılmıştır. Ön değerlendirme sonucu, detaylı bir şekilde incelemeye alınan bilimsel çalışma sayısı toplam 72 olarak belirlenmiştir. Ön değerlendirme süreci Şekil 1'de görülmektedir. 


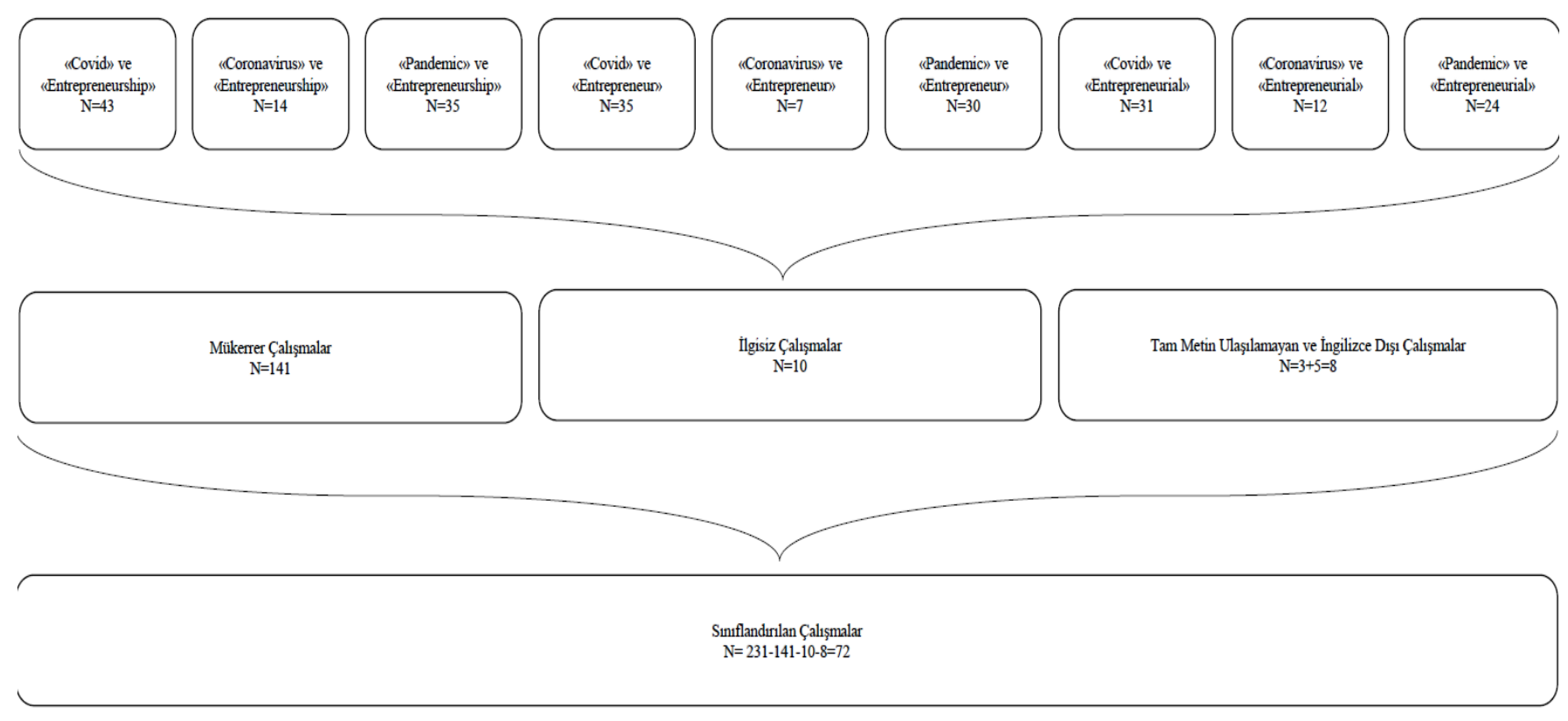

Şekil 1: İlgili Çalışmaların Belirlendiği Ön Değerlendirme

Ön değerlendirme sonucunda elde edilen 72 bilimsel çalışma çeşitli ölçütlere göre sınıflandırılmıştır. Söz konusu ölçütler yazar sayısı, dergi türü, anahtar kelime kullanımı, doğrudan girişimcilik ve pandemi alanlarını birleştirme, bilimsel çalışma türü, çalışma konusu olan girişimcilik düzeyi, araştırma hedefi, araştırma yaklaşımı, veri toplama tekniği ve çalışmanın girişimcilik alanındaki teması olmak üzere 10 tanedir. İlgili ölçütler ve bilimsel çalışmaların kodlanması için analiz çerçevesi Tablo 1 'de verilmektedir.

Tablo 1: Bilimsel Çalışmaların Kodlanması için Analiz Çerçevesi

\begin{tabular}{|l|l|}
\hline Ölçüt & Kodlama \\
\hline Doğrudan Alanları Birleştirme & Ana Odak, Yüzeysel İrdeleme \\
\hline Yazar Sayısı & $1,2,3,4,5$ ve Daha Fazla \\
\hline Dergi Türü & SCI-exp, SSCI, A\&HCI, ESCI \\
\hline Anahtar Kelime Kullanımı & Covid, Girişimcilik, İkisi Birden \\
\hline Bilimsel Çalışma Türü & Orijinal Makale, Yazın Taraması, Perspektif/Görüş/Yorum \\
\hline Girişimcilik Düzeyi & Makro, Mezo, Mikro \\
\hline Araştırma Hedefi & Keşfedici, Betimleyici, Açıklayıcı \\
\hline Araştırma Yaklaşımı & Nitel, Nicel, Karma \\
\hline Veri Toplama Tekniği & Mülakat, Odak Grup, Soru Sorma, Hazır Veri \\
\hline Girişimcilik Teması & 14 Farklı Tema \\
\hline
\end{tabular}

\subsection{Bulgular}

Ön değerlendirme sonucunda 72 çalışmaya ulaşılmış olmasına rağmen söz konusu bazı bilimsel çalışmaların tam anlamıyla Covid-19 pandemi dönemindeki girişimcilik olgusu üzerine odaklanmadığı anlaşılmıştır. Söz konusu bu çalışmaların belli bir kısmı, çalışmayı ilgili dergiye Covid-19 pandemi döneminden önce göndermiş olmakla birlikte Covid-19 pandemisinin etkilerini düzeltmeler sürecinde makaleye eklemlediği izlenimi oluşmuştur. Diğer taraftan pandemi döneminde dergiye gönderilen bazı çalışmalar Covid-19 pandemisi sürecindeki girişimcilik olgusu ile ilgili değilken, iki olgudan birine yüzeysel olarak değindikleri gözlemlenmiştir. Dolayısı ile 72 bilimsel çalışmanın kodlanması sürecinde ilk olarak, pandemi döneminde girişimcilik olgusunu çalışmasının ana odağı yapan ve ilgili alanlardan en az birine yüzeysel değinen çalışmalar sınıflandırılmaktadır. 47 çalışma pandemi döneminde girişimcilik olgusunu ana odağı olarak incelerken, 25 çalışma iki alandan en az birini yüzeysel olarak irdelemektedir. Dağılım Tablo 2'de gösterilmektedir.

Tablo 2: Covid-19 Pandemi Döneminde Girişimcilik Olgusunun Çalışmadaki Yeri

\begin{tabular}{|c|c|}
\hline Ana Odak & Yüzeysel İrdeleme \\
\hline $47(\% 65,28)$ & $25(\% 34,23)$ \\
\hline
\end{tabular}

Gerçekleştirilen çalışmalar irdelendiğinde ilk çalışma, 21 Mart tarihinde yayımlanan Guerrero ve Urbano'nun (2020) çalışmasıdır. Covid-19 pandemisi ve girişimciliği ana odak konusu yapan çalışmaların 2020 Mayıs ayı ile ortaya çıktığı ve sonraki dönemde ilginin süreklilik gösterdiği gözlenmektedir. İlgili alanları yüzeysel olarak değerlendiren çalışmaların aylara göre dağılımı daha tutarsız olmasına karşın, Covid-19 pandemisi ya da girişimciliğin önemli konular olması nedeniyle 
çalışmalarda yer bularak araştırılan konu ile bağlantılarının kurulduğu gözlenmektedir. Bütüncül değerlendirmede, özellikle 2020 Haziran ayından sonra Covid-19 pandemisi ve girişimcilik ile ilgili bilimsel yayın sayılarında önemli bir artış görülmektedir. Çalışmaların en yoğun olduğu 2020 Haziran ve Eylül aylarında sırasıyla 18 ve 16 bilimsel çalışma gerçekleştirilmiştir. Covid-19 pandemisinin girişimcilik üzerindeki etkisini ana odağı yapan çalışmaların 2020 Eylül ayında 11 çalışma $(\% 23,4)$ ile yoğunlaştığı, yüzeysel değinen çalışmaların ise 2020 Haziran ayında daha fazla (\%32,0) olduğu anlaşılmaktadır. Çalışmaların 2020 yılı Kasım ayına kadarki dönemde aylara göre dağılımı Şekil 2'de gösterilmektedir.

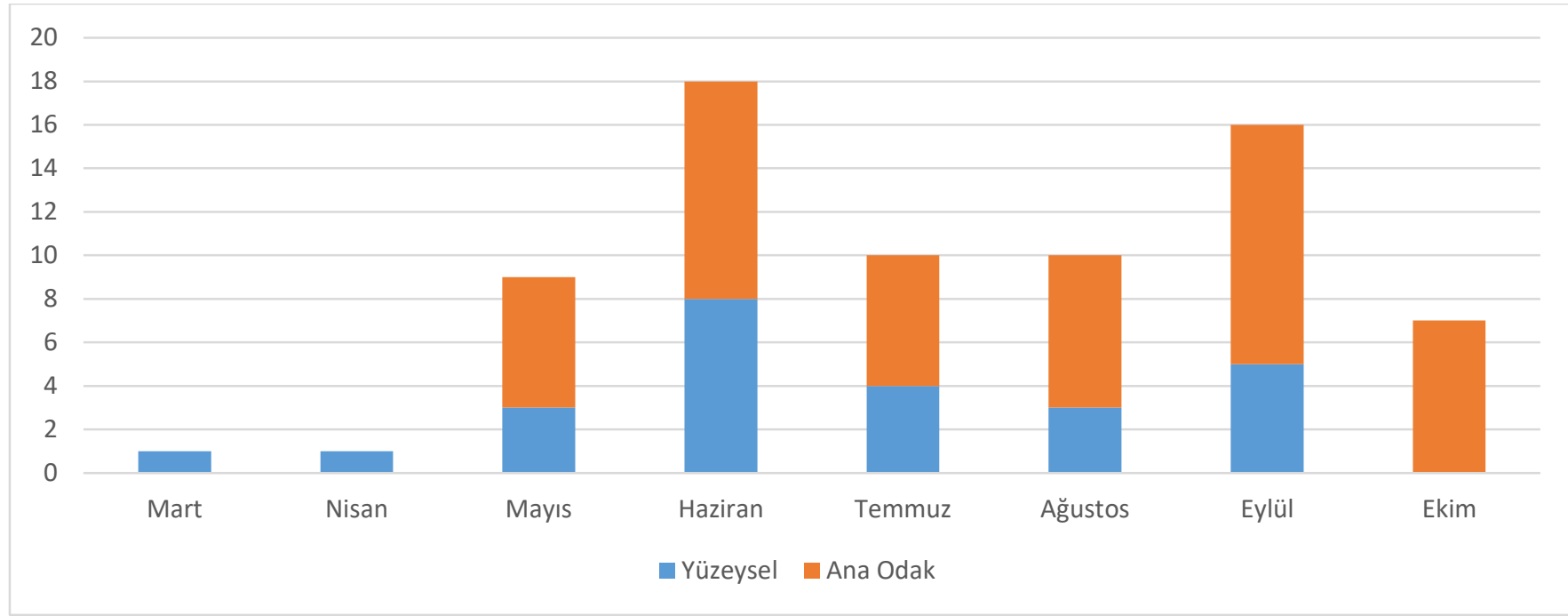

Şekil 2: İlgili Çalışmaların 2020 Yılındaki Aylara Göre Dağılımı

Özellikle Covid-19 pandemisi ve girişimcilik alanı çok disiplinli çalışmaların önünü açabilmektedir. Dolayısı ile farklı disiplinlerdeki araştırmacıların birlikte çalışması ve/veya pandeminin sekiz aylık döneminin bilimsel bir çalışma hazırlamak için yetersiz kalması nedeniyle çalışmaların çok yazarlı olması beklenmektedir. Bu bağlamda gerçekleştirilen kodlama sonucunda çalışmaların \%30'u tek yazarlı, \%70'inin ise çok yazarlı olduğu Tablo 3'te görülmektedir. Ek olarak alana katkı açısından en çok bilimsel çalışma üreten yazar, beş tek yazarlı iki de çok yazarlı olmak üzere yedi çalışma (Ratten, 2020a; 2020b; 2020c; 2020d; 2020e; Ratten ve Jones, 2020; Apostolopoulos, vd., 2020) ile Vanessa Ratten'dir. Bütün bilimsel çalışmaları Covid-19 pandemi döneminde girişimciliği ana odak konusu yapmıştır. Apostolopoulos, Ratten, Stavroyiannis, Makris ve Apostolopoulos'un (2020) 6 yazarlı kırsal sağlık girişimlerini irdeleyen çalışması ise ana odak konusu pandemi dönemindeki girişimcilik olan çalışmalar içinde en çok yazarlı çalışmadır. Yazar sayılarını gösteren dağılım Tablo 3 'te verilmektedir.

Tablo 3: İlgili Çalışmaların Yazar Sayısına Göre Dağılımı

\begin{tabular}{|l|c|c|c|c|c|c|}
\hline Alanları Birleștirme & Yazar Sayısı & $\mathbf{1}$ & $\mathbf{2}$ & $\mathbf{3}$ & $\mathbf{4}$ & $\mathbf{5}$ ve Fazla \\
\hline Ana Odak & $16(\% 34)$ & $8(\% 17)$ & $12(\% 26)$ & $9(\% 19)$ & $2(\% 4)$ \\
\hline Yüzeysel Irdeleme & $5(\% 20)$ & $8(\% 32)$ & $5(\% 20)$ & $5(\% 20)$ & $2(\% 8)$ \\
\hline Toplam & $21(\% 30)$ & $16(\% 22)$ & $17(\% 24)$ & $14(\% 19)$ & $4(\% 5)$ \\
\hline
\end{tabular}

Bilimsel çalışmaların yayımlandığı dergiler açısından yapılan incelemede dergi çeşitliliğinin fazla olduğu görülmektedir. Sadece beş derginin Covid-19 pandemisi ve girişimcilik ile ilgili birden fazla bilimsel çalışmaya sayılarında yer verdiği tespit edilmiştir. 'International Small Business Journal: Researching Entrepreneurship' dergisinin dokuz yayınla Covid-19 pandemisi ve girişimcilik ile ilgili çalışmalara ağırlık verdiği görülmektedir. 'Sustainability' beş yayın, 'Journal of Management Studies', 'Journal of Enterprising Communities: People and Places in the Global Economy', 'Eurasian Chemical Communication' dergileri ise iki yayına ev sahipliği yapmıştır.

Web of Science Core Collection çeşitli endeksleri içinde barındırmaktadır. Bilimsel yayınlar için Science Citation Index Expanded (SCI-Ex.), Social Sciences Citation Index (SSCI), Art \& Humanities Citation Index (A\&HCI) ve Emerging Sources Citation Index (ESCI) araştırmanın konusu olan çalışmaları içeren endeksleri oluşturmaktadır. Yapılan değerlendirme sonucunda 72 bilimsel çalışmanın yayımlandığ fazlasına dahil olan makaleler sıralamadaki en üst endekse göre kodlanmıştır. Sonuçlara göre ana odağı Covid-19 pandemisinde girişimcilik olan çalışmaların önemli bir kısmı SSCI $(\% 57,5)$ endeksindeki dergilerde yer bulurken, konuyu yüzeysel irdeleyen bilimsel çalışmaların ağırlıklı olarak ESCI $(\% 56,0)$ endeksindeki dergilerde yayımlandığı gözlenmektedir. Kodlama sonucu Tablo 4'te gösterilmiştir.

Tablo 4: İlgili Çalışmaların Yayınlandığı Dergilerin Endeksleri

\begin{tabular}{|l|c|c|c|c|}
\hline Alanları Birleştirme $\quad /$ Dergi Kategorisi & SCI-Ex & SSCI & A\&HCI & ESCI \\
\hline Ana Odak & $6(\% 12,8)$ & $27(\% 57,5)$ & - & $14(\% 29,8)$ \\
\hline Yüzeysel Írdeleme & $3(\% 12,0)$ & $8(\% 32,0)$ & - & $14(\% 56,0)$ \\
\hline Toplam & $9(\% 12,5)$ & $35(\% 48,6)$ & - & $28(\% 38,9)$ \\
\hline
\end{tabular}


Araştırma örnekleminde her ne kadar çalışmaların, alanları birleştirme konusunda bir ölçüt belirlenmiş olsa da Covid-19 pandemisi ile girişimcilik olgusunu ana odağına alan çalışmalardan dokuz tanesinin girişimciliği, yedi tanesinin ise Covid-19 pandemisini anahtar kelimeler arasında göstermediği gözlenmiştir. Diğer taraftan iki alandan birini yüzeysel değerlendiren çalışmaların birisi (Sawalha, 2020) ise iki alanla da ilgili anahtar kelimelerden faydalanmıştır. Sawalha (2020) çalışmasında geleneksel afet yönetimi döngüsünü modern yönetim kapsamı ile irdelerken Covid-19 pandemisinin afet yönetimi kapsamında değerlendirilebileceğini, girişimsel yaklaşımın da afet yönetiminde önem arz ettiğini ifade ederek iki alanla da bağlantı kurmuş ve çalışmasına iki anahtar kelimeyi de eklemiştir. Ana odak olarak konuyu inceleyen dört bilimsel çalışmada ve konuyu yüzeysel irdeleyen iki bilimsel çalışmada anahtar kelimelere rastlanmamıştır. Geriye kalan bilimsel çalışmaların anahtar kelimelerindeki Covid-19 ve girişimcilik ile ilgili dağılımı aşağıdaki Tablo 5 'te bulunmaktadır.

Tablo 5: İlgili Çalışmaların Anahtar Kelimelerine Göre Dağılımları

\begin{tabular}{|l|c|c|c|}
\hline Alanları Birleştirme / Anahtar Kelimeler & Covid-19 & Girişimcilik & Covid-19 ve Girişimcilik \\
\hline Ana Odak* & $9(\% 19,2)$ & $7(\% 14,9)$ & $27(\% 57,45)$ \\
\hline Yüzeysel Irdeleme** & $9(\% 36)$ & $13(\% 52)$ & $1(\% 4)$ \\
\hline Toplam & $18(\% 25)$ & $20(\% 27,8)$ & $28(\% 38,9)$ \\
\hline
\end{tabular}

Özellikle pandeminin olumsuz etkilerini azaltabilmek adına dünya genelinde ilgili çalışmaların yayımlanma hızının arttığı gözlenmektedir. Bilimsel yayın türleri incelendiğinde orijinal makale, yazın taraması ve perspektif/görüş/yorum çalışmaları araştırma merakını farklı düzlemlerde tartışmaktadır. Araştırma sürecinde toplanan yeni verinin (springer.com) ve dolayısıyla yeni olan bir araştırmanın raporlandığı, birincil yazın olarak da ifade edilen bilimsel çalışmalara orijinal araştırma denmektedir (Majumder, 2015). Yazın taramaları, belli bir konuda yapılan araştırmaların kapsamlı bir şekilde özetlendiği ve alanın durumu ile nereye doğru evrildiğini ortaya koyan bilimsel çalışma türüdür (springer.com). Diğer taraftan perspektif/yorum/görüş çalışmaları konu ile ilgili derin bilgisi olan bir araştırmacının mevcut soruna, temel bir kavrama ya da yaygın bir düşünceye ilişkin yeni ve/veya eşsiz görüşünü ortaya koyması ya da yeni uygulanmış inovasyonun göstergelerini tartışmak istemesi ile ortaya çıkan bilimsel çalışmadır (Berterö, 2016).

Mart ayından itibaren dünya geneline yayıldığı kabul edilen Covid-19 pandemisinin üzerine yeni veriler kullanarak raporlanan orijinal makale üretiminin beklenildiği üzere az kaldığ 1 görülmektedir. Bu bağlamda, yazın taraması çalışmalarının da özellikle yeni bir sürecin etkilerini tartışmak konusunda yeterli bilimsel çalışmanın birikmemesi nedeniyle fazla olmadığ görülmektedir. Özellikle, söz konusu sekiz ayda Covid-19 döneminde girişimciliğin etkilenmesi, Covid-19 döneminin sonunda oluşan krizin girişimcilik üzerindeki etkileri gibi önemli konuların araştırmacıların merakını tetiklemesi nedeniyle perspektif/görüş/yorum niteliğindeki bilimsel çalışmaların sayısının azımsanmayacak miktarda olduğu Tablo 6'da da görülmektedir.

Tablo 6: İlgili Çalışmaların Bilimsel Çalışma Türüne Göre Dağılımları

\begin{tabular}{|l|c|c|c|}
\hline Alanları Birleştirme / Bilimsel Çalışma Türü & $\begin{array}{c}\text { Orijinal } \\
\text { Makale }\end{array}$ & $\begin{array}{c}\text { Yazın } \\
\text { Taraması }\end{array}$ & $\begin{array}{c}\text { Perspektif / } \\
\text { Görüş / Yorum }\end{array}$ \\
\hline Ana Odak & $19(\% 40,4)$ & $5(\% 10,7)$ & $23(\% 48,9)$ \\
\hline Yüzeysel Irdeleme & $13(\% 52)$ & $5(\% 20)$ & $7(\% 28)$ \\
\hline Toplam & $32(\% 44,4)$ & $10(\% 13,9)$ & $30(\% 41,7)$ \\
\hline
\end{tabular}

İlgili çalışmaların girişimcilik olgusunu değerlendirdiği düzeyler farklılık göstermektedir. Girişimcilik çalışmalarını düzeylerine göre sınıflandırırken Wortman'ın (1987) çalışması dikkate alınmıştır. Wortman (1987: 262) çalışmasında girişimcilik alanının araştırma tipolojisini teorik, tarihi, çevresel, örgütsel ve işlevsel olarak sınıflandırmaktadır. İşlevsel olarak girişimcilik yazınını birey ve firma düzeyinde ayrımlamış, çevreyi de makro ve mikro çevre olarak irdelemiştir. Bu yaklaşımdan destek alınarak girişimcilik ile ilgili çalışmalar üç düzey üzerinden değerlendirilmiştir. Söz konusu düzeyler; birey düzeyinde mikro, örgüt düzeyinde mezo ve girişimcilik ekosistemi düzeyinde makro olarak kodlanmıştır. Söz konusu olguyu birey düzeyinde ele alan mikro düzeydeki çalışmalar; yeni işletme kurulumu, uygulama, iş birlikleri ya da dış paydaşlar ile ilişkiler üzerinden tartışıyorsa mikro yapısal olarak; kariyer olarak girişimcilik, kişisel özellikler, iş özellikleri gibi değişkenler üzerinden tartış1lyyorsa mikro davranışsal olarak etiketlenmiştir. Olguyu örgüt düzeyinde değerlendiren mezo düzeydeki çalışmalar, yeni girişim kurulumu, işletme modelleri, yatırım yönetimi, inovasyon, teknoloji yönetimi gibi konuları irdeliyorsa mezo yapısal; örgütlerin girişimsel özelliklerini değerlendiriyorsa mezo davranışsal olarak kodlanmıştır. Bilimsel çalışma, ekosistemi bütüncül olarak ya da ekosistemde girişimcilerin dışında kalan ve girişimciliği etkileyen paydaşların rollerini değerlendiriyorsa makro düzey olarak kabul edilmiştir.

Mikro ve mezo düzeydeki araştırmaların, makro düzeye görece daha yoğunlaştığı görülmektedir. Bireylerin Covid-19 ile değişen koşullarda oluşan firsatlara yönelik inovatif faaliyetleri ve işletme kurulumuna yoğunlaşan çalışmalar nedeniyle Covid19 dönemindeki girişimcilik faaliyetlerini ana odağı kabul eden çalışmaların önemli bir kısmının mikro yapısal (\%40,4) çalışmalar olduğu görülmektedir. Örgüt düzeyindeki mezo çalışmalarda ise stratejilere ve uygulamalara odaklanan yapısal çalışmaların (\%29,8) ağırlıklı olduğu görülmektedir. Hem mezo davranışsal çalışmaların $(\% 4,2)$ hem de girişimcilik ekosistemi ve ekosistem paydaşlarını irdeleyen makro çalışmaların $(\% 12,8)$ az çalışılan alanlar arasında olduğu tespit edilmiştir. Yüzeysel irdeleme yapan çalışmalarda mezo yapısal çalışmaların ağırlığ $1 \% 40,0)$ dikkat çekerken, mikro davranışsal çalışmaların $\% 4,0$ düzeyinde kaldığı görülmektedir. Bütün çalışmalar göz önüne alındığında mikro $(\% 47,2)$ ve mezo düzeyin $(\% 41,7)$ yakın 
oranlarda seyrettiği gözlenirken makro düzeydeki çalışmaların azlığı $(\% 11,1)$ dikkat çekicidir. İlgili değerler Tablo 7 'de sunulmaktadır.

Tablo 7: İlgili Çalışmaların Girişimcilik Olgusunun Düzeyine Göre Dağılımı

\begin{tabular}{|l|c|c|c|c|c|}
\hline \multirow{2}{*}{ Alanları Birleştirme / Düzey } & \multicolumn{2}{|c|}{ Mikro } & \multicolumn{2}{|c|}{ Mezo } & \multirow{2}{*}{ Makro } \\
\cline { 3 - 6 } & Yapısal & Davranışsal & Yapısal & Davranışsal & \\
\hline Ana Odak & $19(\% 40,4)$ & $6(\% 8,5)$ & $14(\% 29,8)$ & $2(\% 4,2)$ & $6(\% 12,8)$ \\
\hline Yüzeysel Irdeleme & $8(\% 32,0)$ & $1(\% 4)$ & $10(\% 40,0)$ & $4(\% 16,0)$ & $2(\% 8,0)$ \\
\hline Toplam & $27(\% 37,5)$ & $7(\% 9,7)$ & $25(\% 34,7)$ & $5(\% 7,0)$ & $8(11,1)$ \\
\hline
\end{tabular}

Ana odağı Covid-19 pandemi dönemindeki girişimcilik olgusu olan bilimsel çalışmaların araştırma hedefi ağırlıklı olarak betimleyici olmuştur. Diğer taraftan nitel yaklaşım ile toplanan veriler yoluyla söz konusu dönemdeki girişimcilik sorunlarının ve girişimcilik uygulamalarının anlaşılmaya çalışıldığı keşfedici çalışmaların da \%21,3'lük oranı bulunmaktadır. Özellikle Covid-19 pandemisinin etkilerinin net olarak ortaya çıkmaması, sürecin devam etmesi, 2020 yılı finansal raporların 2021 yılının ilk çeyreğinde açıklanacak olması söz konusu veriler ile gerçekleştirilecek açıklayıcı çalışmaların mevcut durumda \%8,5 düzeyinde kalmasına neden olmaktadır. Ek olarak Covid-19 dönemindeki girişimcilik faaliyetlerini yüzeysel irdeleyen çalışmalarda, araştırma hedeflerinin yüzdesel dağılımı özellikle betimleyici çalı̧̧alarda $(\% 72,0)$ farklı değildir. Fakat, söz konusu yayınlarda açıklayıcı çalışmaların, keşfedici çalışmalara oranla daha fazla olduğu görülmektedir. Bütün çalışmalar irdelendiğinde ise oluşan koşullar dahilinde betimleyici çalışmaların yoğunlukta $(\% 70,8)$ olduğu Tablo 8'de görülmektedir.

Tablo 8: İlgili Çalışmaların Araştırma Hedeflerine Göre Dağı̆lımı

\begin{tabular}{|l|c|c|c|}
\hline \multicolumn{1}{|c|}{ Alanları Birleştirme / Araştırma Hedefi } & Keşfedici & Betimleyici & Açıklayıcı \\
\hline Ana Odak & $10(\% 21,3)$ & $33(\% 70,2)$ & $4(\% 8,5)$ \\
\hline Yüzeysel İrdeleme & $2(\% 8,0)$ & $18(\% 72,0)$ & $5(\% 20,0)$ \\
\hline Toplam & $12(16,7)$ & $51(\% 70,8)$ & $9(\% 12,5)$ \\
\hline
\end{tabular}

Orijinal makalelerin araştırma yöntemi ve veri toplama teknikleri farklılaşmaktadır. Karma teknikten faydalanan çalışmaların ana odak çalışmaları içerisinde kaldığı ve 32 çalışma içinde sadece üç tanesinin $(\% 9,7)$ karma yaklaşımı benimsediği Tablo 9'da görülmektedir. Bütün örneklem değerlendirildiğinde ise nicel çalışmaların yoğunlukta olduğu $(\% 54,8)$ bulgulanmıştır. Öte yandan ana odak olarak sınıflandırılan nitel yaklaşımlı bilimsel çalışmaların \%75'i mülakat tekniği ile veri toplamıştır.

Tablo 9: İlgili Orijinal Makalelerin Araştırma Yaklaşımları ve Veri Toplama Tekniklerine Göre Dağılımları

\begin{tabular}{|c|c|c|c|c|}
\hline Alanları Birleştirme / & Araştırma Yaklaşımı & Nitel & Nicel & Karma \\
\hline \multirow[t]{5}{*}{ Ana Odak } & Mülakat & $6(\% 31,6)$ & - & $2 *(\% 5,3)$ \\
\hline & Odak Grup & $1(\% 5,3)$ & - & - \\
\hline & Anket & - & $3(\% 15,8)$ & $2 *(\% 5,3)$ \\
\hline & Hazır Veri & $1(\% 5,3)$ & $5(\% 26,3)$ & $1(\% 5,3)$ \\
\hline & Toplam & $8(\% 42,1)$ & $8(\% 42,1)$ & $3(\% 15,8)$ \\
\hline \multirow[t]{4}{*}{ Yüzeysel İrdeleme } & Mülakat & $2(\% 15,4)$ & - & - \\
\hline & Soru Sorma & - & $4(\% 30,8)$ & - \\
\hline & Anket & $2(\% 15,4)$ & $5(\% 38,4)$ & - \\
\hline & Toplam & $4(\% 30,8)$ & $9(\% 69,2)$ & - \\
\hline Toplam & & $12(\% 38,7)$ & $17(\% 54,8)$ & $3(\% 9,7)$ \\
\hline
\end{tabular}

İlgili makalelerde çalışılan konular 14 ayrı başlık altında toplanmaktadır. En çok tartışılan konu 17 bilimsel çalışmanın değindiği firsat girişimciliğ̉i/inovasyon olanağı doğrultusunda girişimcilik firsatı temasıdır. Özellikle iki alanın ortak noktasına yüzeysel değinen 10 çalışma (\%40'1); sürecin uçak/havayolu (Goritiyal ve Goritiya, 2020), turizm (Varelas ve Apostolopoulos, 2020), tarım (Zhang vd., 2020) ve tekstil (Lowe ve Vinodrai, 2020) gibi sektörlerde önemli firsatlar getirdiğini ve yaşanan değişimlerin kadın futbolu (Clarkson vd., 2020), aile işletmeleri (Ratten ve Jones, 2020; Salvato vd., 2020) ve mimari yapılanma (Lai vd., 2020) gibi konularda yeniden tasarlanması gereken boşluklar yarattığını belirtmekte ve oluşan konjonktürün girişimciliği tetikleyebileceğine vurgu yapmaktadırlar. Covid-19 pandemisi ve girişimcilik alanlarını doğrudan odak konusu olarak kabul eden çalışmalarda ise söz konusu firsatların oluştuğuna değinmekten öte mevcut durum, durumun etkileri ve/veya çözüm önerileri ile konuyu irdelemektedirler. Covid-19 pandemi sürecinde oluşan firsatları ve işletmelerin bu firsatlara tepkilerini (Morgan vd., 2020), pandeminin yarattığı sorunların çözümünde inovasyon ve girişimciliğin rolünü (Lui vd., 2020), turizm sektöründeki döngüsel ekonomiye geçişte inovasyonun ve sosyal girişimciliğin nasıl konumlandığını (Ateljevic, 2020), İtalyan girişimcilerin hangi firsatları değerlendirdiğini (Centorrino, 2020) ya da toplantı ve kongrelerde nasıl inovatif çözümler ile pandemi sorunun üstesinden gelinebileceğini (Dashper ve Finkel, 2020) doğrudan araştırma konusu yapmaktadırlar.

Çalışma yapılan girişimcilik temaları arasında en çok değinilen ikinci tema sosyal girişimciliktir. Özellikle Covid-19 pandemisinin sosyal kurumları ve sosyal hayatı değiştirmesiyle (Desa ve Jia, 2020; Ratten, 2020a; 2020c; Bacq ve Lumpkin, 2020) sosyal girişimciliğin önem kazanacağı görüşünün (Bacq ve Lumpkin, 2020; Bacq vd., 2020; de Falco ve Renzi, 2020; Tung, 2020; Guerrero ve Urbano, 2020; Galetska vd., 2020; Saiz-Alvarez vd., 2020) tartışılmasına yol açtığı düşünülmektedir. 
Bu genel kanının aksine Ruiz-Rosa ve çalışma arkadaşları (2020) pandeminin yarattığı çevresel belirsizliğin sosyal girişimcilik niyetini azalttığını ifade etmektedirler.

Girişimcilik uygulamalarında; strateji, politika ve yöntemler değerlendirilmiştir. Mikro, mezo ve makro olmak üzere üç düzeyde de pandemi döneminde strateji ve politika geliştirerek neler yapıldığını tartışan 11 çalışma tespit edilmiştir. Batat (2020) gıda hizmet sektöründeki Michelen yıldızına sahip 12 İtalyan şefin hangi stratejileri benimsediğini tartışmaktadır. Benzer şekilde Omar ve çalışma arkadaşları (2020) girişimcilerin hangi sorunlarla karşılaştığını ve nasıl çözülebileceğini tartışırken; küçük ve orta ölçekli işletmelerin (KOBİ) (Guo vd., 2020; Korsgaard vd., 2020) ya da çok uluslu işletmelerin (Lorenzen vd., 2020) uygulamalarının irdelenmesi gerçekleştirilen çalışmalar arasındadır. Dobrowlski’ye göre (2020) Covid-19 pandemisine yönelik alınan önlemler yetersiz kalıp girişimcilik açısından riskler oluşturmaktadır. Morris (2020) Covid-19 gibi olayların neden olduğu ciddi ekonomik dalgalanmaların finansal açıdan güçlü olmayan girişimlerin üzerindeki olumsuz sonuçları doğurarak yoksulluğu tetiklediğini ve politik önlemlerin alınması gerektiğini ifade etmektedir. Lim ve diğerleri de (2020) 2008 krizinin etkileri üzerinden Covid-19 pandemisinin olası etkilerini tartışarak alınması gereken önlemler ve yapılması gereken uygulamaları ortaya koymaktadır. Yine bu dönemde finansal kuruluşların değişen düzlemde uygulaması gereken politikaları (Al-Sarraf, 2020) da irdelenmektedir. Ayrıca inovasyon yönetiminin de pandemi dönemindeki önemi tartışılan (Herstatt ve Tiwari, 2020; Sawalha, 2020) konular arasındadir.

İşletme kurulum sürecinde Covid-19 pandemisinin etkilerine karşı gerçekleştirilen çalışmalarda girişimcilerin pandemiye yönelik algıları (Weinhardt ve Bartosch, 2020) ve yaşadığı sorunları (Nummela vd., 2020) tartışılırken pandemi öncesi ve sonrası durumun karşılaştırıldığı (Maritz vd., 2020) çalışmalar da bulunmaktadır. Mikro düzey çalışmaların yanı sıra KOBİ'ler üzerine gerçekleştirilen çalışmalar (Beland vd., 2020; Cowling vd., 2020; Roy vd., 2020) yeni girişimlerin kurulumunda yaşanacak sıkıntılar üzerine odaklanmaktadır.

Girişimcilerin özelliklerinin farklılaşması üzerine gerçekleştirilen çalışmaların, özellikle kadın girişimciler (Manolova vd., 2020; Mathew vd., 2020; Jaim 2020; Grandy vd., 2020) üzerine odaklandığı görülmektedir. Ek olarak, cinsiyetin yanı sıra ırk, etnik köken ve göçmenlik gibi diğer farklılıkların da irdelendiği bütüncül bir çalışmaya (Fairlie, 2020) rastlanmıştır.

Lumpkin ve Dess (1996) tarafından kavramsallaştırılan girişimsel yönelim, Covid-19 pandemisi ile dört bilimsel çalışmada irdelenmiştir. Covid-19 pandemi sürecinde girişimsel yönelim olgusunun; örgüt performansı (Cannavale vd., 2020), Porter'1n Beş Güç Yaklaşımı (Isabelle vd., 2020), tedarik zinciri yönetimi (Ketchen ve Craighead, 2020) ve sürdürülebilir tarım işletmesi (Smith, vd., 2020) kavramları çerçevesinde değerlendirildiği gözlenmiştir.

Girişimcilik ekosistemi üzerine gerçekleştirilen iki çalışma bulunmaktadır. Uluslararası işletmelerin, girişimsel ekosistem bakış açısıyla Covid-19 pandemisinden etkilenmelerini tartışan Ratten (2020d) ve pandeminin işletme çevresindeki olumsuz etkilerinin en aza indirilmesi için devletin mali araçlarına yönelik politika önerileri getiren Hudelcu (2020) pandemi ile girişimcilik ekosisteminin etkileşimini tartı̧̧maktadırlar.

Normal dönemde bile ciddi bir sorun olan sermayeye erişim, pandemi döneminde artan 'finansal uzaklık' (Howell vd., 2020) nedeniyle girişimcilik faaliyetlerini daha da yavaşlatabilmektedir (Brown ve Rocha, 2020). Rizvi ve diğerleri (2020) pandemi döneminde yatırımların nasıl bir dönüşüm yaşadığını tartışırken, Brown, Rocha ve Cowling (2020) hisse temelli kitle fonlama ile destek alan girişimlerin boylamsal olarak nasıl değiştiğini ortaya koymaktadır.

Bütün söz konusu temalara ek olarak Covid-19 pandemi sürecinin kırsal sağlık girişimciliği (Apostolopoulos vd., 2020), akademik girişimcilik (Greene ve Rosiello, 2020), ev eksenli üretim/gayri resmi girişimcilik (Saleh, 2020), iç girişimcilik (Carnevale ve Hatak, 2020), spor girişimciliği (Ratten, 2020e), girişimci üniversite (Blackmore, 2020), girişimcilik niyeti (Hernandez-Sanchez vd., 2020), dijital girişimcilik (Zemtsov, 2020) ve teknik girişimcilik (Wilson ve Halverson, 2020) gibi niş temalarında da çalışmaların gerçekleştirildiği Tablo 10'da görülmektedir.

Tablo 10: İlgili Çalışmaların Araştırma Nişlerine Göre Dağılımı

\begin{tabular}{|c|c|c|c|c|c|c|c|c|c|c|c|c|c|c|c|c|c|c|}
\hline \multicolumn{2}{|c|}{$\begin{array}{c}\text { Alanları } \\
\text { Birleştirme/Araştırma Nişi }\end{array}$} & \multirow{2}{*}{ 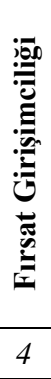 } & \multirow{2}{*}{ 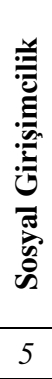 } & \multirow{2}{*}{ 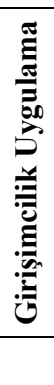 } & \multirow{2}{*}{ 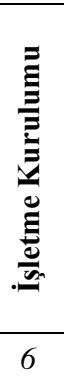 } & \multirow{2}{*}{ 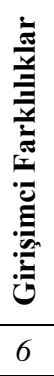 } & \multirow{2}{*}{ 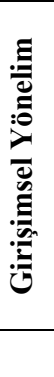 } & \multirow{2}{*}{ 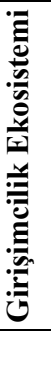 } & \multirow{2}{*}{ 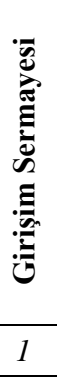 } & \multirow{2}{*}{ 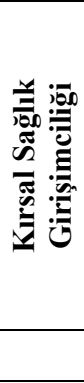 } & \multirow{2}{*}{ 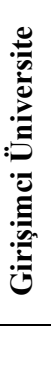 } & \multirow{2}{*}{ بَ: } & \multirow{2}{*}{ 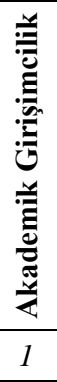 } & \multirow{2}{*}{ 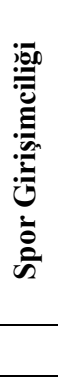 } & \multirow{2}{*}{ 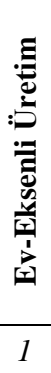 } & \multirow{2}{*}{ 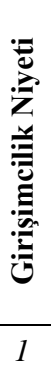 } & \multirow{2}{*}{ 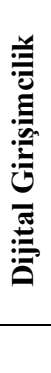 } & \multirow{2}{*}{ 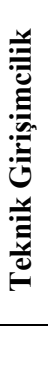 } \\
\hline \multirow{4}{*}{ Ana Odak } & Mikro & & & & & & & & & & & & & & & & & \\
\hline & Mezo & 2 & 4 & 5 & 2 & & & & 1 & & & 1 & & 1 & & & & \\
\hline & Makro & 1 & & 1 & & & & 2 & & 1 & 1 & & & & & & & \\
\hline & Toplam & 7 & 9 & 6 & 8 & 6 & - & 2 & 2 & 1 & 1 & 1 & 1 & 1 & 1 & 1 & & \\
\hline \multirow{2}{*}{$\begin{array}{l}\text { Yüzeysel } \\
\text { Írdeleme }\end{array}$} & Mikro & 5 & & 1 & 1 & & & & & & & & & & & & 1 & 1 \\
\hline & Mezo & 5 & 3 & 2 & & & 4 & & & & & & & & & & & \\
\hline
\end{tabular}




\begin{tabular}{|c|c|c|c|c|c|c|c|c|c|c|c|c|c|c|c|c|c|}
\hline Makro & & & 2 & & & & & & & & & & & & & & \\
\hline Toplam & $\mathbf{1 0}$ & $\mathbf{3}$ & $\mathbf{5}$ & $\mathbf{1}$ & & $\mathbf{4}$ & & & & & & & & & & $\mathbf{1}$ & \\
\hline Toplam & $\mathbf{1 7}$ & $\mathbf{1 2}$ & $\mathbf{1 1}$ & $\mathbf{9}$ & $\mathbf{6}$ & $\mathbf{4}$ & $\mathbf{2}$ & $\mathbf{2}$ & $\mathbf{1}$ & $\mathbf{1}$ & $\mathbf{1}$ & $\mathbf{1}$ & $\mathbf{1}$ & $\mathbf{1}$ & $\mathbf{1}$ & $\mathbf{1}$ & $\mathbf{1}$ \\
\hline
\end{tabular}

\section{SONUÇ}

Covid-19 pandemisinin ekonomiler ve toplumlar üzerinde benzeri görülmemiş düzeyde yarattığı karışılık (Gibson, 2020) ancak bireysel, örgütsel ve kurumsal düzeyde verilen karşıllklar ve bütün paydaşların yüksek seviyedeki koordinasyonu ile yönetilebilecektir (Liu vd., 2020: 278). Bu durum, girişimcilik olgusu açısından da hem çeşitli firsatlar yaratması (Morgan vd., 2020) hem de tehditler oluşturması açısından ilgi çekicidir. İlgili araştırmaların hangi düzlemde olduğunu değerlendiren çalışmanın sonuçları, ilerleyen dönemde çalışmaların sayısının artacağına dair bir gelişme olduğunu göstermektedir. Özellikle ilerleyen dönemde yüz yüze görüşmelerin olanaklı hale gelmesi, Covid-19 pandemisinin bireysel girişimlere yönelik etkilerini irdeleyen çalışmaların çoğalacağını düşündürmektedir. Benzer şekilde makro ekonomik verilerin de su yüzüne çıkması ile açıklayıcı çalışmaların artacağı düşünülmektedir. Çünkü makro ekonomik veri eksikliğinin özellikle makro düzeydeki girişimcilik çalışmalarının görece çok az sayıda gerçekleşmesine neden olduğu düşünülmektedir.

Özellikle 2021 yılı ortalarında aşının geliştirilecek ve yaygınlaşacak olması ile yüz yüze ve odak grup görüşmelerin olanaklı hale gelmesi ve keşifsel çalışmaların artacağı düşünülmektedir. Öte yandan, Covid-19 pandemisinin erken etkisini değerlendirebilmek için gereksinim duyulan verilerin açıklanmamış olması nedeniyle girişimcilik ve işletmelerin nasıl etkilendiğini araştırmak olanaklı olamamaktadır (Fairlie, 2020: 727). 2021 yılında 2020 y1lına ait finansal ve makro ekonomik resmi verilerin açıklanması ile mezo ve makro düzeyde açıklayıcı çalışmaların sayısında çok ciddi bir artış olması beklenmektedir.

Betimleyici çalışmaların yine eksik veriler nedeniyle yoğun olarak pandeminin firsat kapıları araladığı vurgusunun ötesine geçememelerine neden olmaktadır. Pandeminin etkilerinin belirginleşmesi ile görece daha az araştırılan nişlerin üzerine gerçekleştirilecek çalışmaların artacağı düşünülmektedir.

Araştırmanın kısıtlarından ilki, veri tabanı olarak 'Web of Science Core Collection' ile örneklemin oluşturulmasıdır. Söz konusu veri tabanı güvenilirlik ve seçim ölçütlerinin kalitesi nedeniyle tercih edilmiştir. Araştırmanın bir diğer kısıtı, anahtar kelime tercihleridir. Söz konusu anahtar kelimelerin, girişimcilik ve pandemi ile ilgili çalışmaları kapsayıcı olduğu kabul edilmiştir.

Gelecek çalışmalarda farklı endekslerde taranan dergilerdeki çalışmaların da dikkate alınarak yazın taraması yapılabilir. Özellikle pandeminin küresel salgın olarak kabul edilmesinin yıl dönümü olan 2021 Mart ayı itibari ile 2020 yılının pandemiden nasıl etkilendiğine dair çalışmaların yoğunlaşması, araştırma sonuçlarını farklılaştırabileceği düşünülmektedir. Bu çalışma sonuçlarının Covid-19 pandemisini girişimcilik olgusu ile değerlendiren çalışmaların seyrini ortaya koyması açısından, ilgili alanda çalışma yapacak diğer araştırmacılara yol gösterici olacağı düşünülmektedir.

\section{KAYNAKÇA}

Aceytuno, M. T., Sánchez-López, C. \&, Paz-Báñez, M.A. (2020). Rising Inequality and Entrepreneurship during Economic Downturn: An Analysis of Opportunity and Necessity Entrepreneurship in Spain. Sustainability, 12, 4540.

Acs, Z., \& Armington, C. (2004). Employment Growth and Entrepreneurial Activity in Cities. Regional Studies, 38(8), 911-927.

Al-Sarraf, A. (2020). Bankruptcy Reform in The Middle East and North Africa: Analyzing The New Bankruptcy Laws in The UAE, Saudi Arabia, Morocco, Egypt, and Bahrain. International Insolvency Review, 29(2), 159-180.

Antoncic, B., \& Hisrich, R. D., (2003). Clarifying the Intrapreneurship Concept. Journal of Small Business and Enterprise Development, 10(1), 7-24.

Apostolopoulos, N., Ratten, V., Stavroyiannis, S., Makris, I., Apostolopoulos, S., \& Liargovas, P. (2020). Rural Health Enterprises in The EU Context: A Systematic Literature Review and Research Agenda. Journal of Enterprising Communities: People and Places in the Global Economy, 14(4) 563-582.

Ateljevic, I. (2020). Transforming The (Tourism) World for Good and (Re)Generating The Potential 'New Normal'. Tourism Geographies, 22(3), 467-475.

Audretsch, D. (2012). Entrepreneurship Research. Management Decision. 50(5), 755-764.

Bacq, S., \& Lumpkin, G. T. (2020) Social Entrepreneurship and Covid-19. Journal of Management Studies, https://onlinelibrary.wiley.com/doi/full/10.1111/joms.12641

Bacq, S., Geoghegan, W., Josefy, M., Stevenson, R., \& Williams, T. A. (2020). The COVID-19 Virtual Idea Blitz: Marshaling Social Entrepreneurship to Rapidly Respond to Urgent Grand Challenges. Business Horizons. 63(6), 705-723. 
Batat, W. (2020). How Michelin-Starred Chefs are Being Transformed into Social Bricoleurs? An Online Qualitative Study of Luxury Foodservice During The Pandemic Crisis, Journal of Service Management. https://doi.org/10.1108/JOSM-052020-0142

Baumol, W. J. (1968). Entrepreneurship in Economic Theory. The American Economic Review, 58(2), 64-71.

Beland, L. P., Fakorede, O., \& Mikola, D. (2020). Short-Term Effect of COVID-19 on Self-Employed Workers in Canada. Canadian Public Policy, 46(1), 66-81.

Berterö, C. (2016). Guidelines for Writing A Commentary. International Journal of Qualitative Studies on Health and WellBeing, 11. https://www.ncbi.nlm.nih.gov/pmc/articles/PMC4789530/

Blackmore J. (2020). The Carelessness of Entrepreneurial Universities in A World Risk Society: A Feminist Reflection on The Impact of Covid-19 in Australia, Higher Education Research \& Development, https://doi.org/10.1080/07294360.2020.1825348

Brown, R., \& Rocha, A. (2020). Entrepreneurial Uncertainty During The Covid-19 Crisis: Mapping The Temporal Dynamics of Entrepreneurial Finance. Journal of Business Venturing Insights, https://www.sciencedirect.com/science/article/pii/S2352673420300305?casa_token=cC8F1KiaAsAAAAAA:wFuozDLoR22BDP8tKkUx_t3AzcWx3V4nXmOTEEP0rA2Bn6T4ZwdyXKtgQ4DM8edtXixPIerbbB

Brown, R., Rocha, A., \& Cowling, M. (2020). Financing Entrepreneurship in Times of Crisis: Exploring The Impact of COVID19 on The Market for Entrepreneurial Finance in The United Kingdom. International Small Business Journal, 38(5), 380-390.

Burgelman, R. A. (1983) A Process Model of Internal Corporate Venturing in Diversified Major Firm. Administrative Science Quarterly, 28 (2), 223-244

Cadar, O., \& Badulescu, D. (2015). Entrepreneur, Entrepreneurship and Intrapreneurship. A Literature Review. 02/10/2020 tarihinde https://mpra.ub.uni-muenchen.de/82793/1/MPRA_paper_78871.pdf adresinden alınd1.

Cannavale, C., Zohoorian Nadali, I. and Esempio, A. (2020). Entrepreneurial Orientation and Firm Performance in A Sanctioned Economy - Does The CEO Play A Role?, Journal of Small Business and Enterprise Development, 27(6), 1005-1027.

Carnevale, J. B., \& Hatak, I. (2020). Employee Adjustment and Well-Being in The Era of COVID-19: Implications For Human Resource Management. Journal of Business Research. 116, 183-187.

Centorrino, G. (2020). Covid-19 and the Search for the Common Good: The Case of Parmon Spa (Italy). Sustainability, 12(16), 6657.

Clarkson B., Culvin, A., Pope, S., \& Parry, K. D., (2020). Covid-19: Reflections on Threat and Uncertainty for The Future of Elite Women's Football in England, Managing Sport and Leisure, https://doi.org/10.1080/23750472.2020.1766377

Covin, J. G., \& Slevin, D. P. (1991). A Conceptual Model of Entrepreneurship as Firm Behavior. Entrepreneurship Theory and Practice, 16(1), 7-26.

Cowling, M., Brown, R., \& Rocha, A. (2020). Did You Save Some Cash for A Rainy COVID-19 Day? The Crisis and SMEs. International Small Business Journal, 38(7), 593-604.

Czarniawska-Joerges, B., \& Wolff, R. (1991). Leaders, Managers, Entrepreneurs on and Off The Organizational Stage. Organization Studies, 12(4), 529-546.

Dashper, K., \& Finkel, R. (2020, September). Accessibility, Diversity, and Inclusion in The UK Meetings Industry. Journal of Convention \& Event Tourism, 21(4), 283-307.

Desa, G., \& Jia, X. (2020). Sustainability Transitions in The Context of Pandemic: An Introduction to The Focused Issue on Social Innovation and Systemic İmpact. Agriultural Human Values 37, 1207-1215.

Dobrowolski, Z. (2020). The Supreme Audit Institutions Readiness to Uncertainty. Entrepreneurship and Sustainability Issues, $8(1), 513-525$.

Dorin, C., \& Alexandru, G. S. (2014). Dynamics of The Entrepreneurship Concept. Literature Review. The Annals Of The University Of Oradea, 23(1), 443-451.

Dy, A. M., \& Jayawarna, D. (2020). Bios, Mythoi and Women Entrepreneurs: A Wynterian Analysis of The Intersectional Impacts of The COVID-19 Pandemic on Self-Employed Women and Women-Owned Businesses. International Small Business Journal, 38(5), 391-403.

Esposito De Falco, S., \& Renzi, A. (2020). Benefit Corporations and Corporate Social Intrapreneurship, Entrepreneurship Research Journal, 10(4), 20200382. https://doi.org/10.1515/erj-2020-0382

Fairlie, R. (2020). The Impact Of COVID-19 on Small Business Owners: Evidence from The First 3 Months after Widespread Social-Distancing Restrictions. Journal of Economics \& Management Strategy, 29(4), 727-740. 
Fillion, L. J. (2011) Defining The Entrepreneur. World Encyclopedia of Entrepreneurship (Ed. Dana, L. P.,), 41-52, Massachussets: Edward Elgar Publishing.

Fossen, F.M. (2020). Self-Employment over The Business Cycle in The USA: A Decomposition. Small Business Economics, 586. https://doi.org/10.1007/s11187-020-00375-3

Galetska, T., Natalya, T., \& Topishko, I. (2020). Social Responsibility of Economic Enterprises as A Social Good: Practice of The EU and Ukraine. Baltic Journal of Economic Studies, 6(3), 24-35.

Gibson, C. (2020). From "Social Distancing" to "Care in Connecting": An Emerging Organizational Research Agenda for Turbulent Times. Academy of Management Discoveries, 6(2), 165-169.

Goritiyal, C. \& Goritiyal, L. (2020), An Entrepreneurial Opportunity in Civil Aviation \& Defence Aerospace Sector in India, Pacific Business Review International, 12(12), 126-132.

Grandy, G., Cukier, W. \& Gagnon, S. (2020). (In)Visibility in The Margins: COVID-19, Women Entrepreneurs and The Need For Inclusive Recovery, Gender in Management. https://doi.org/10.1108/GM-07-2020-0207

Greene, F. J., \& Rosiello, A. (2020). A Commentary on The Impacts of 'Great Lockdown'and Its Aftermath on Scaling Firms: What are The İmplications for Entrepreneurial Research?. International Small Business Journal: Researching Entrepreneurship, 38(7), 583-592.

Guerrero, M., \& Urbano, D. (2020). Institutional Conditions and Social Innovations in Emerging Economies: Insights From Mexican Enterprises' Initiatives for Protecting/Preventing The Effect of Violent Events. The Journal of Technology Transfer, 45:929-957.

Guo, H., Yang, Z., Huang, R., \& Guo, A. (2020). The Digitalization and Public Crisis Responses of Small and Medium Enterprises: Implications from a COVID-19 Survey. Frontiers of Business Research in China, 14(1), 1-25.

Hernández-Sánchez, B. R., Cardella, G. M., \& Sánchez-García, J. C. (2020). Psychological Factors that Lessen the Impact of COVID-19 on the Self-Employment Intention of Business Administration and Economics' Students from Latin America. International Journal of Environmental Research and Public Health, 17(15), 5293. https://doi.org/10.3390/ijerph17155293

Herstatt, C., \& Tiwari, R. (2020). Opportunities of Frugality in the Post-Corona Era. 02/10/2020 tarihinden http://cfi.globalinnovation.net/wp-content/uploads/2020/06/Working_Paper_110-1.pdf adresinden alınd1.

Hechavarria, D. M.,\& Ingram, A. E. (2019). Entrepreneurial Ecosystem Conditions and Gendered National-Level Entrepreneurial Activity: A 14-Year Panel Study of GEM, Small Business Economics, 53(2), 431-458.

Howell, S., Lerner, J., Nanda, R., \& Townsend, R., (2020). Financial Distancing: How Venture Capital Follows The Economy Down and Curtails Innovation. Harvard Business School Working Paper, 01/10/2020 tarihinde https://www.nber.org/papers/w27150.pdf adresinden alınd1.

Hudelcu, D. (2020). Fiscal Instruments to Protect the Business Environment in Times of Pandemic. Postmodern Openings, 11(3), 344-358.

Isabelle, D., Horak, K., McKinnon, S., \& Palumbo, C. (2020). Is Porter's Five Forces Framework Still Relevant? A Study of The Capital/Labour Intensity Continuum via Mining and IT Industries. Technology Innovation Management Review, 10(6), 28-41.

Jaim, J. (2020). Exist or exit? Women business-owners in Bangladesh during COVID-19. Gender, Work \& Organization. https://doi.org/10.1111/gwao.12546.

Ketchen Jr, D. J., \& Craighead, C. W. (2020). Research at the Intersection of Entrepreneurship, Supply Chain Management, and Strategic Management: Opportunities Highlighted by COVID-19. Journal of Management, 46(8), 1330-1341.

Kuratko D. F. ve Hodgetts R. M. (1988). Entrepreneurship. Orlando: The Dreyden Press.

Lengnick-Hall, C. A. (1992). Innovation and Competitive Advantage: What We Know and What We Need to Learn. Journal of Management, 18(2), 399-429.

Lim, D. S., Morse, E. A., \& Yu, N. (2020). The Impact of The Global Crisis on The Growth of SMEs: A Resource System Perspective. International Small Business Journal, 38(6), 492-503.

Korsgaard, S., Hunt, R. A., Townsend, D. M., \& Ingstrup, M. B. (2020). COVID-19 and The Importance of Space in Entrepreneurship Research and Policy. International Small Business Journal: Researching Entrepreneurship. https://journals.sagepub.com/doi/full/10.1177/0266242620963942

Lai, S., Leone, F., \& Zoppi, C. (2020). Covid-19 and Spatial Planning. TeMA - Journal of Land Use, Mobility and Environment, 231-246. 
Liu, Y., Lee, J. M., \& Lee, C. (2020). The Challenges and Opportunities of A Global Health Crisis: The Management and Business Implications Of COVID-19 From An Asian Perspective. Asian Business \& Management, 19, $277-297$.

Lorenzen, M., Mudambi, R., \& Schotter, A. (2020). International Connectedness and Local Disconnectedness: MNE Strategy, City-Regions and Disruption. Journal of International Business Studies, 51(8), 1199-1222.

Low, M. B., \& MacMillan, I. C. (1988). Entrepreneurship: Past Research and Future Challenges. Journal of Management, 14(2), 139-161.

Lowe, N., \& Vinodrai, T. (2020). The Maker-Manufacturing Nexus as a Place-Connecting Strategy: Implications for Regions Left Behind. Economic Geography, 96(4), 315-335.

Lumpkin, G. T., \& Dess, G. G. (1996). Clarifying The Entrepreneurial Orientation Construct and Linking it To Performance. Academy of Management Review, 21(1), 135-172.

Majumder, K. (2015). 6 Article Types That Journals Publish: A Guide for Early Career Researchers, 07/10/2020 tarihinde https://www.editage.com/insights/6-article-types-that-journals-publish-a-guide-for-early-career-researchers adresinden alındi.

Manolova, T. S., Brush, C. G., Edelman, L. F., \& Elam, A. (2020). Pivoting to Stay The Course: How Women Entrepreneurs Take Advantage of Opportunities Created by The COVID-19 Pandemic. International Small Business Journal, 38(6), 481-491.

Maritz, A., Perenyi, A., de Waal, G., \& Buck, C. (2020). Entrepreneurship as The Unsung Hero During The Current COVID-19 Economic Crisis: Australian Perspectives. Sustainability, 12(11), 4612.

Mathew, N., Deborah, I., Karonga, T., \& Rumbidzai, C. (2020). The Impact of COVID-19 Lockdown in A Developing Country: Narratives of Self-Employed Women in Ndola, Zambia, Health Care for Women International. https://doi.org/10.1080/07399332.2020.1823983

McKee, D. O., Varadarajan, P. R., \& Pride, W. M. (1989). Strategic Adaptability and Fir m Performance: A MarketContingent Perspective. Journal of Marketing, 53(3), 21-35.

Miles, R. E., Snow, C. C., Meyer, A. D. ve Coleman, H. J. (1978). Organizational Strategy, Structure and, Process. Academy of Management Review, 3(3), 546-562.

Mirza, N., Naqvi, B., Rahat, B., \& Rizvi, S. K. A. (2020). Price Reaction, Volatility Timing and Funds’ Performance during Covid-19. Finance Research Letters, 36, 101657.

Morgan, T., Anokhin, S., Ofstein, L., \& Friske, W. (2020). SME Response to Major Exogenous Shocks: The Bright and Dark Sides of Business Model Pivoting. International Small Business Journal, 38(5), 369-379.

Morris, M. H. (2020). The Liability of Poorness: Why the Playing Field is Not Level for Poverty Entrepreneurs. Poverty \& Public Policy, 12(3), 304-315.

Neumeyer, X., Ashton, W. S., \& Dentchev, N. (2020). Addressing Resource and Waste Management Challenges Imposed by COVID-19: An Entrepreneurship Perspective. Resources, Conservation and Recycling, 162, 105058.

Nummela, N., Paavilainen-Mäntymäki, E., Harikkala-Laihinen, R., \& Raitis, J. (2020). When All Doors Close: Implications of COVID-19 for Cosmopolitan Entrepreneurs. International Small Business Journal: Researching Entrepreneurship. https://journals.sagepub.com/doi/full/10.1177/0266242620954127

Omar, A. R. C., Ishak, S., \& Jusoh, M. A. (2020). The Impact Of Covid-19 Movement Control Order on Smes’ Businesses and Survival Strategies. Geografia-Malaysian Journal of Society and Space, 16(2), 139-150.

Pandey, J., Chakraborty, S., Chakraborty, I., Ghosal, P., Singh, N., \& Majumdar, S. (2020). Can Developing Countries Handle The Mental Burden due to The Lockdown Situation?: Understanding The Uncertainty and Management of Covid-19 Pandemic. Asia Pacific Journal of Health Management, 15(3), 72-79.

Ratten, V. (2020a). Coronavirus (Covid-19) and Entrepreneurship: Cultural, Lifestyle and Societal Changes, Journal of Entrepreneurship in Emerging Economies. https://doi.org/10.1108/JEEE-06-2020-0163

Ratten, V. (2020b). Coronavirus (Covid-19) and The Entrepreneurship Education Community, Journal of Enterprising Communities: People and Places in the Global Economy. https://doi.org/10.1108/JEC-06-2020-0121

Ratten, V. (2020c). Coronavirus (covid-19) and Social Value Co-Creation, International Journal of Sociology and Social Policy. https://doi.org/10.1108/IJSSP-06-2020-0237

Ratten, V. (2020d). Coronavirus and International Business: An Entrepreneurial Ecosystem Perspective. Thunderbird International Business Review, 62(5), 629-634.

Ratten, V. (2020e). Coronavirus Disease (COVID-19) and Sport Entrepreneurship, International Journal of Entrepreneurial Behavior \& Research, 26(6), 1379-1388. 
Ratten, V., \& Jones, P. (2020). Enhancing Policies and Measurements of Family Business: Macro, Meso or Micro Analysis, Journal of Family Business Management. https://doi.org/10.1108/JFBM-07-2020-0062

Rizvi, S. K. A., Mirza, N., Naqvi, B., \& Rahat, B. (2020). Covid-19 and Asset Management in EU: A Preliminary Assessment of Performance and Investment Styles. Journal of Asset Management, 21, 281-291.

Ruiz-Rosa, I., Gutiérrez-Taño, D., \& García-Rodríguez, F. J. (2020). Social Entrepreneurial Intention and the Impact of COVID19 Pandemic: A Structural Model. Sustainability, 12(17), 6970. https://doi.org/10.3390/su12176970

Roy, A., Patnaik, B. C. M., \& Satpathy, I. (2020). Impact of Covid-19 Crisis on Indian MSME Sector: A Study on Remedial Measures. Eurasian Chemical Communications, 2(9), 991-1000.

Roy, A., Patnaik, B. C. M., \& Satpathy, I. (2020b). Consolidated Recommendations to Change GST Patterns for Managing The Impact Of Covid-19: A Case in India. Eurasian Chemical Communications, 2(9), 1011-1020.

Saiz-Álvarez, J. M., Vega-Muñoz, A., Acevedo-Duque, Á., \& Castillo, D. (2020). B Corps: A Socioeconomic Approach for The COVID-19 Post-Crisis. Frontiers in Psychology, 11, 1987. doi: 10.3389/fpsyg.2020.01867

Saleh, Y. (2020). ICT, Social Media And COVID-19: Evidence from Informal Home-Based Business Community in Kuwait City, Journal of Enterprising Communities: People and Places in the Global Economy, https://doi.org/10.1108/JEC07-2020-0131

Salvato, C., Sargiacomo, M., Amore, M. D., \& Minichilli, A. (2020). Natural Disasters as A Source of Entrepreneurial Opportunity: Family Business Resilience after An Earthquake. Strategic Entrepreneurship Journal. https://doi.org/10.1002/sej.1368

Sawalha, I.H. (2020). A Contemporary Perspective on The Disaster Management Cycle, Foresight, 22(4), 469-482.

Shepherd, D. A. (2020). COVID 19 and Entrepreneurship: Time to Pivot?. Journal of Management Studies. https://doi.org/10.1111/joms.12633

Śledzik, K. (2013). Schumpeter's View on Innovation and Entrepreneurship. Management Trends in Theory and Practice,(Ed. Hittmar E.), Faculty of Management Science and Informatics, University of Zilina \& Institute of Management by University of Zilina.

Smith, A. M., Duncan, P., Edgar, D., \& McColl, J. (2020). Responsible and Sustainable Farm Business: Contextual Duality as The Moderating Influence on Entrepreneurial Orientation. The International Journal of Entrepreneurship and Innovation. https://doi.org/10.1177/1465750320944702

Snow, C. C. ve Hrebiniak, L. G. (1980). Strategy, Distinctive Competence, and Organizational Performance. Administrative Science Quarterly, 25(2), 317-336.

Tödtling, F., \& Wanzenböck, H. (2003). Regional Differences in Structural Characteristics of Start-ups. Entrepreneurship \& Regional Development, 15(4), 351-370.

Tung, L. T. (2020). Social Responses for Older People in COVID-19 Pandemic: Experience from Vietnam. Journal of Gerontological Social Work, https://doi.org/10.1080/01634372.2020.1773596

van den Hoogen, B., Santoni, A., Sciumé, G., Bowie, A., O’Farrelly, C., O’Neill, L., ... \& Manel, N. (2020). Immunometabolism Pathways as The Basis for Innovative Anti-Viral Strategies (INITIATE): A Marie Sklodowska-Curie Innovative Training Network. Virus Research, 287, 198094.

Van de Ven, A. H., Hudson, R., \& Schroeder, D. M. (1984). Designing new business startups: Entrepreneurial, organizational, and ecological considerations. Journal of management, 10(1), 87-108.

Varelas, S., \& Apostolopoulos, N. (2020). The Implementation of Strategic Management in Greek Hospitality Businesses in Times of Crisis. Sustainability, 12(17), 7211. https://doi.org/10.3390/su12177211

Weinhardt, M., \& Bartosch, J. (2020, June). Surveying Entrepreneurs' Perception of Society in Times of Corona: A proposal. Survey Research Methods, 14(2), 147-151.

Wennekers, S., \& Thurik, R. (1999). Linking Entrepreneurship and Economic Growth. Small Business Economics, 13(1), 27-56.

Wilson, T. E., \& Halverson, C. (2020). Home Testing for COVID-19: Lessons from Direct to Consumer Genetics. Journal of Community Genetics, 11(4), 497-499.

Wortman Jr, M. S. (1987). Entrepreneurship: An Integrating Typology and Evaluation of The Empirical Research in The Field. Journal of Management, 13(2), 259-279.

Zemtsov, S. (2020). New Technologies, Potential Unemployment and 'Nescience Economy'during and after The 2020 Economic Crisis. Regional Science Policy \& Practice. 12(4), 723-743. 
Zhang, Y., Diao, X., Chen, K.Z., Robinson, S. and Fan, S. (2020). Impact Of COVID-19 on China's Macroeconomy and AgriFood System - An Economy-Wide Multiplier Model Analysis, China Agricultural Economic Review, 12(3), $387-407$.

www.webofknowledge.com

https://www.mckinsey.com/industries/public-and-social-sector/our-insights/us-small-business-recovery-after-the-covid-19crisis

WwW.springer.com

https://www.who.int/emergencies/diseases/novel-coronavirus-2019/ 